INDEPENDENT JOURNAL OF MANAGEMENT \& PRODUCTION (IJM\&P)

http://www.ijmp.jor.br

v. 5, n. 4, October - December 2014

ISSN: 2236-269X

DOI: 10.14807/ijmp.v5i4.243

\title{
IMPLEMENTATION OF DISTRIBUTION CENTERS AS LOGISTICS COMPETITIVE ADVANTAGE: STUDY ON OIL COMPANY DISTRIBUTOR IN SOUTHEAST BRAZIL
}

\author{
Henrique Albernaz \\ CEFET/RJ, Brazil \\ E-mail: henriquealbernazfreitas@gmail.com \\ Ursula Gomes Rosa Maruyama \\ CEFET/RJ, Brazil \\ E-mail: maruyama.academic@hotmail.com \\ Marcelo Sampaio Dias Maciel \\ CEFET/RJ, Brazil \\ E-mail: msdmaciel@gmail.com \\ Fernando Ramos Correa \\ CEFET/RJ, Brazil \\ E-mail: frcorrea@gmail.com
}

Submission: $12 / 06 / 2014$

Revision: 25/06/2014

Accept: 01/07/2014

\section{ABSTRACT}

This study aims to present how distribution centers implementation in organization is able to provide a competitive advantage. The qualitative research was based on multiple case studies. Thus, the cases were focused on lubricants segment national distribution company. It was intended to introduce improvements recognizing distribution centers (DCs) importance as competitive advantage. DC Macaé-RJ and DC Piracicaba-SP were chosen to represent this scenario. Therefore, as results it was found increased sales and operating leverage within the market in which it operates.

Keywords: Logistics, distribution center, transportation. 


\section{INTRODUCTION}

In order to present a study on the benefits a company can achieve through the deployment of distribution centers in its logistics network, this study aimed to list improvements and differentiation opportunities which generated competitive advantage for a Brazilian organization.

The research question deals with the following issue: how companies acquire their advantage over its competitors, and how could it use as a basis for structuring logistics through distribution centers? The purpose was to analyze them as a way to acquire a competitive advantage in sales, reducing costs and increasing its market share.

Therefore this paper presents how is possible to achieve this enhancement through Distribution Centers (DCs), making an organization able to optimize their processes and becoming a stronger company in its segment.

This study was delimited in geographical point of view analyzing the Brazilian scenario and based on the lubricant segment, focused on a branch company headquartered in Rio de Janeiro and two distribution centers implemented in MacaéRJ and Piracicaba-SP. In the present study this organization was defined as Company $\mathrm{X}$.

After a theoretical framework and lubricants market national scenario, the work focused on presenting the benefits brought by logistics operation. Thus, through fractional distribution from DCs there is a reduction of delivery time (lead time), freight costs, as well as levels of damage in transport reduction.

Subsequently multiple case study developed based on two warehouses that have been implemented as distribution. Thus, it will be possible to identify a number of opportunities which enabled Company $X$ to achieve the objectives mentioned above.

Yet, specialist filled a survey with the addressed issues in order to strengthen the understanding of the benefits exposed. At the end, the research results have proven that DCs structure can boost sales, generating competitive advantage and cost savings. 


\section{LOGISTICS AND ITS CONCEPTS}

In general, logistics can be defined as the administration area responsible for managing the transport and storage of raw materials and goods. Based on this definition, we can understand logistics as an area accountable for managing the entire process of product transport management from raw materials supplier up to its production towards end consumer.

Associated to supplier feasible lowest cost and meeting customer expectations, logistics compliance is met on the deadline and without affecting product quality. Similarly, Novaes (2001) identifies the logistics as:

[...] the process of planning, implementing and controlling efficiently the flow and storage of goods and services and associated information, covering from point of origin to the consumer, in order to meet the requirements of consumer (NOVAES, 2001, p. 30).

Considering how logistics is associated to the materials management throughout supply chain another definition arises "is the management of the flow of materials and information of a business, through the distribution channel to the end consumer" (SLACK, 2002, p. 416). Another point to present around the definition of logistics is that it is fully linked to business strategy, how a company believes that should manage its inventory levels and its distribution.

Fleury (2000) acknowledges two basic lines of transformations from most modern logistics management concepts: economics and technology. The economic transformations create a distinctive environment and new demands in the market. In addition, technological changes allow logistics to be increasingly seen with a quite significant strategic role for organization success and not only been as its operational function.

For these reasons companies come to appreciate logistics, because they understand the sector performance in its organization may be able to create a competitive advantage over competitors. According to Ballou (2006), in recent years business administration has been concerned with this coordination of logistics activities. It is also possible to understand the potential savings arising from logistics management review which are transforming the discipline.

It is worth remembering the definition of logistics provided by Bowersox \& Closs (2001) as a process of information management, transportation, inventory 
management and storage, information transfer, material handling and packaging of a cohesive manner to generate all the capacity required to meet the logistical requirements. Finally it is important to mention logistics definition made by the Council of Logistics Management as:

[...]Supply Chain Management part which plans, implements and controls the flow and storage efficiently and cost of raw materials, semi-finished materials and finished products, as well as the related information from the point of origin to point of consumption in order to meet customer requirements (CARVALHO, 2002, p. 31).

Thus it is possible to understand how logistics is important within companies, and through good management decision making is possible the organization achieve its goals, new customers and new markets, as well as strengthening partnership with existing ones.

\section{ORGANIZATIONAL LOGISTICS}

It is due to logistics the responsibility for controlling throughout materials or products transportation within internal and external organizational environment (inbound logistics and outbound logistics): from the arrival of raw materials to final consumer product delivery. One can define some logistics primary activities as:

- Transportation: It is on the way to carry the load of the company, the use of modal choice efficiently and effectively.

- Inventory management: It is on the defining level of inventory to meet demand without increasing costs.

- Order processing: It is connected to the definition of lead-time and order of service charges for customers.

Primary activities described above according to Ballou (2006, p.41), has great influence on the efficiency and effectiveness of both production and marketing of company goods. In addition, there are other logistics secondary activities such as:

- Storage: It is related space issues and shaping the way of storage.

- Material Handling: It is on the internal movement of products.

- Packing: It is related to the definition of packaging used with "only" purpose product protection.

- Programming: Responsible for defining the routes for products distribution to customers.

- Control: Provides systems and database for location definition, tracking within enterprise warehouses, besides providing an accounting control over these materials. 
Besides these activities, for an organization, logistics have great connection on company strategy and the level of customer service, once delivery is often the final link between supplier and customer. Thus, good logistics service is accountable for customer retention and,

[...] logistics not only involves management and different activities coordination, but also has an operational function which could be unfolded: cut costs, speed up implementation of activities and improve customer service (MORENO, 2001, p. 4).

This work intends to present logistics chain assembled efficiently, so the company can influence and achieve customer loyalty, cost savings and other benefits focusing on distribution centers.

\section{DISTRIBUTION CENTER (DC)}

The distribution center (DC) cannot be considered a mere deposit, because their function is greater than just a warehouse. The DC has importance within a logistics system theme which this project aims to explain in more detail further.

The DC is a kind of warehouse positioned in a strategic location with a logistic function defined by the company, where loads are received in bulk from one or more suppliers. Upon load reception they are fractionated to group of items in smaller quantities so they can later be dispatched to closer dealers and customers.

In order to point out a difference between a warehouse and a DC, Alves (2000) shows that public deposits work in push system, because they are "plants whose main purpose is to store products to offer customers" While DCs, work on the pull system, they are "facilities whose purpose is to receive products just in time so as to meet customers' needs."

The basic DC functions according to Calazans (2001) are: receipt, handling, storage, order picking and shipping. Moreover, Garnier ranked physical distribution centers as "sequential, direct or mixed" (GARNIER apud CALAZANS, 2001).

Relating what was reported by these authors, it can be said that when a commodity arrives at a DC, it can be stored or shipped immediately, the latter operation is called cross docking. When a load is stored for later dispatch it should be placed in position and properly inserted in the control system.

When Garnier (CALAZANS, 2001) says that DCs can be considered sequential or direct, means that a company which uses DCs sequentially passes to 
DOI: 10.14807/ijmp.v5i4.243

load multiple DCs until it reaches final destination. On the other hand, company that makes the option for direct shipping model is the load matrix to the nearest DC of final consumer.

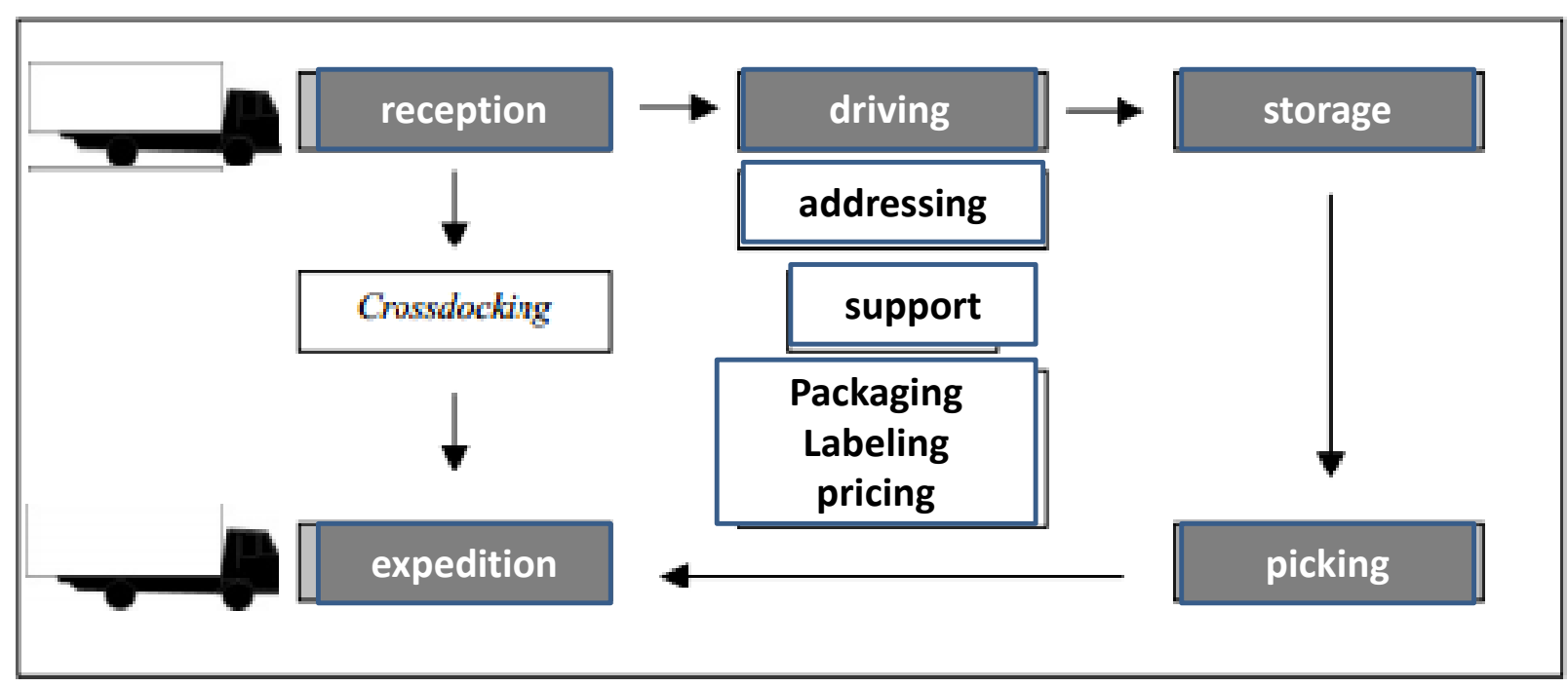

Figure 1: DC basic functions.

Source: Adapted from Calazans (2001)

Another concept related to DC is the concept of Advanced Distribution Center (ADC), which functions the same as the DC, but it is located in a strategic point. For instance, a set point that will bring many benefits to the company is to meet certain range of clients, tax benefits, creating a competitive advantage over its competitors.

To Pizzolato \& Pinho (2003), companies should consider according to their market segment and according to their interests be resolved to act with few or many DCs, i.e. whether to centralize or decentralize its distribution, taking into account the costs and customer service.

Regarding the Brazilian scenario, because it is a country with continental dimensions it is necessary to have large portfolio of clients throughout the country in order to make strategic decisions about where to deploy their footholds, as well as to be able to serve all locations with greater efficiency.

Thus, deployment of an ADC (Advanced Distribution Center) may bring advantage to the organization and this work as previously stated aims to show in more detail how to use these sites adequately bringing benefit to the company, choosing to study a branch company of lubricants on the national scene. 


\section{LUBRIFICANTS MARKET ON THE NATIONAL SCENARIO ANALYZED}

Lubricating oils are divided into two categories which are: mineral and synthetic. Mineral oil is extracted by burning oil as is done in the generation of fuels such as gasoline and kerosene. On the other hand, synthetic oil is laboratory made from the polymerization of ethylene which forms the basis of synthetic oil.

Lubricants are used to reduce friction between two surfaces, lower temperature and increase the lifetime of a particular device. In Brazil, there are 13 kinds of base oils. The present work aims to treat mainly logistics and not the technical part on lubricating oils per se, just explaining the main types such as: turbine, neutral, drum and naphthenic.

The finished lubricant is a combination of one or more base oils and additives combined to create a particular applicability to oil. Also in this family have lubricating greases which are of high viscosity or pastes by mixing lubricating oil and thickening agents. Greases are generally used in bearings from a smaller scale as wheel hubs of vehicles by automotive bearings such as ball bearings high impacts of hydroelectric plants and sugar cane plants. And thus giving continuity to the issues explored in this work will be shown a set of information about lubricants market on the national scene.

\subsection{Lubricants National Market}

In this section data on the domestic market will be presented to explain the competition in the industry so that later can be shown the implementation of ADCs used to gain competitive advantage over its competitors.

Sales of industrial lubricants in $\mathrm{m}^{3}\left(1 \mathrm{~m}^{3}=1000\right.$ liters $)$ :

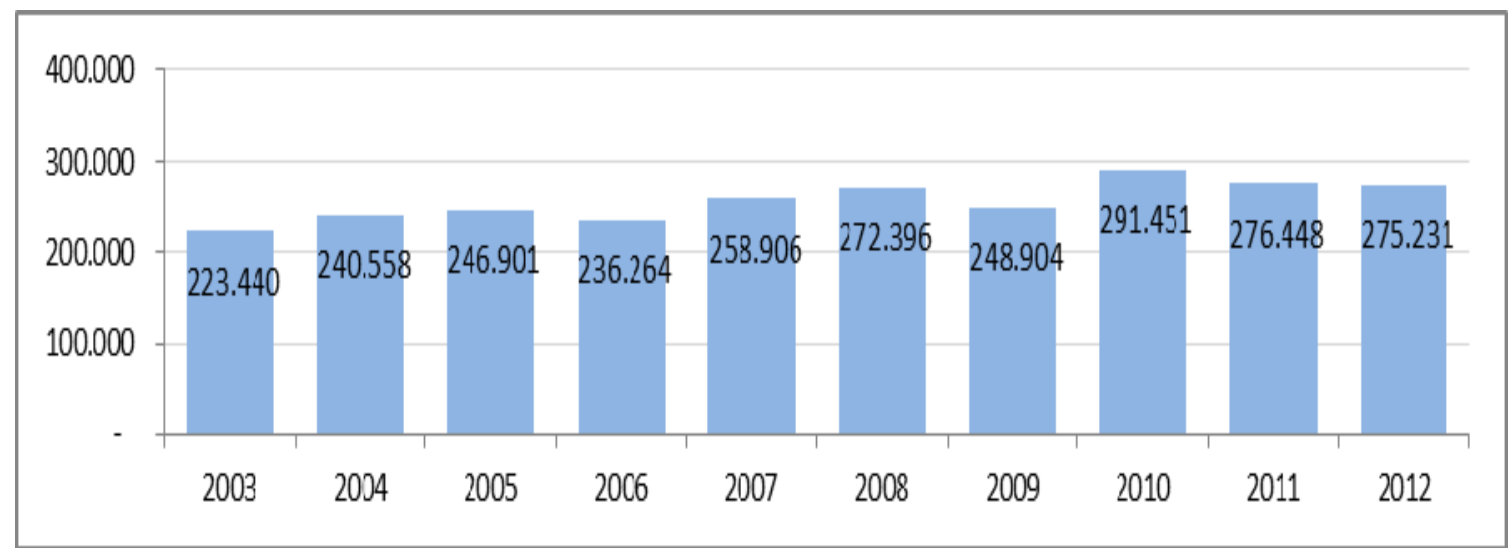

Graph 1: Sales Volume of Industrial Lubricants.

Source: Adapted from Sindicom (2014) 
Considering all forms of sales, approximately $1.044 \mathrm{~m}^{3}$ lubricating oils sold per month since 2003. Another important aspect to be highlighted in this work is related to the composition of the market share in the segment analyzed.

\subsection{Competitors and growth estimates}

The lubricants market in Brazil is currently a very competitive and very hot niche. As shown previously, companies in recent years changed their positions in the market share, except of the first place all other institutions had changed its position.

The company was analyzed during the crop year 2008 a fifth place with $11.2 \%$ of market share and a second place at the end of year 2012 with $14.6 \%$ market share. Thus in a very competitive market is of paramount importance that companies seek alternatives and measures that make a difference to build a competitive advantage over their competitors so they can raise their sales ability and thus acquire a larger market share.

The segment has been getting in recent years a steady growth. According to ANP considering only the finished product, 2011 sales volume was 1.369 million $\mathrm{m}^{3}$ and 2012, 1.383 million $\mathrm{m}^{3}$ which shows an increase of only $1 \%$ in the period. And as the same agency expected a small increase in the coming years due to this strong environmental laws that cause many companies to stop marketing the lubricant per year and others end up increasing the values of its products to meet all standards related to product.

In recent years the National Petroleum Agency (ANP in Portuguese) engages with maximum focus on lubricants quality marketed in Brazil. There is currently a program of monitoring the quality of lubricants which has helped reduce the rate of nonconformities relating to product quality, in 2011 were about $20.7 \%$, then it was reduced to $16.3 \%$ in 2012 .

\section{MULTIPLE CASE STUDIES: SCENARIO ANALYSIS}

Company $X$ is one of the largest producers of oil and grease lubricants in Brazil, operates throughout the country and exports to the following countries: Argentina, Bolivia, Uruguay and Paraguay. Its pillars are based on meeting total customer satisfaction, innovation and safety in all operations. 
The headquarters and production plant are located in Rio de Janeiro and currently has four distribution centers in Brazil: DC- Piracicaba, DC- Manaus, DC Suape and DC Macae, besides having 24 distributors throughout Brazil. The company is currently in second place in market share and growing through its bold growth plan and implementation of distribution centers.

In 2008 a large Brazilian business group acquired control of the company, as well as the right to produce and market one of the most recognized brands of lubricating oils in the world. From this time the big company managers have become concerned and move to the company had the necessary conditions to be able to acquire more market share and competitive advantage over its competitors.

\subsection{Enterprise status in $\mathbf{2 0 0 8}$}

In 2008, when the company became part of one big Brazilian conglomerate it was developed a planning team to propose a series of transformations in the company structure and processes. Thus, it would be possible to increase sales, reduce costs and, therefore, increase their participation in market share.

By that time, the company occupied the 5th place in sales in its segment. It was realized that in order to achieve a larger share of this market it would be necessary restructuring of logistic model adopted by the company. Up to that moment the direct sales load distribution to distributors as well as to end customers was executed by the factory. This behavior should be modified, though.

Associated with this intention of gaining competitive advantage over its competitors, it was applied survey and planning of the benefits achieved through DCs implementation.

\subsection{Benefits identification and planning}

Logistics planning identified benefits from distributions centers implementation. Henceforth, it was established between years 2008 and 2012 it would be deployed four distribution centers in Manaus-AM, Piracicaba-SP, Macaé-RJ and Suape-PE. A number of benefits were identified through distribution centers based on operational, tax, or the related to cost reduction issues.

The first issue addressed was the lead time because its reduction directly impacts the organization and customer service level. When a company starts 
DOI: 10.14807/ijmp.v5i4.243

allocating its inventory closer to customer locations range, delivery time is reduced by bringing competitive advantage, presenting this issue as strategic utmost importance.

This structure enables client maintaining lower level of stock. In addition it keeps a lower safety stock leaving room to customer reducing costs and investing more in its core needs. What generally brings the benefit of reducing delivery time brings greater customer satisfaction. Henceforth this reduction also facilitates reverse logistics.

Through DCs it is possible to consolidate the load before sending to DC, the company is able to send its products to transfer its subsidiaries into larger carts sostocking charge, which in general reduces the cost of shipping. In addition it is also possible to improve modal consolidating shipping charge. As an example we can consider cabotage which generally requires more travel time than land transport, but it has reduced costs and risks of failure.

Another important point is the possibility of reducing the shipping cost using the railroad. Despite the insufficient Brazilian railroad mesh, it is still quite satisfactory in certain regions. The product amount and path narrowing aim to show that individual shipments should cover as much distance as possible, with the largest volume cargo as possible, and this capability can be leveraged through a network of warehouses (BOWERSOX; CLOSS; COOPER, 2002, p. 375).

The warehouses and branches implementation can bring largest potential to reduce insurance-related costs in freight transport. This question is based on the ability to carry cargo transportation in a modal reduced insurance cost compared to traditional road transport.

But even when choosing to use the same modal - in this case the road transportation - the company will be able to reduce their costs on cargo insurance, because it is based on the product value carried. Usually cargo insurance is often called ad-valorem rate: it is composed of risk management and insurance itself, both based on the invoice value.

And when a company is performing a transfer to an affiliate invoice value will be based on their products standard price, which means a price without profit (mark up), which is obviously much lower than invoice value transported directly to customers. 
From DCs factory would reduce their storage spots and optimizing this area to production and development, once its stock would be distributed over several DCs. In this aspect the survey team identified benefits the company would gain because it currently faces great difficulty in expanding its base oil tanks volume.

The scenario survey led them to choose such locations and subsequently two cases chosen to be presented in this paper: Macaé-RJ and Piracicaba-SP, both in Brazilian Southeast region. In the last section of this material the overall benefits that were key factors in opening DCs will be shown.

\subsection{Case study 1: Distribution Center in Macaé-RJ}

DC Macaé was on the need to improve service to clients: from diverse marine region, several attendance bases to small vessels, large oil rigs and other large companies that have facilities in the region, reasons that were leveraged to select the region to deploy a warehouse.

As described earlier in this paper, every lead time reduction is an interesting competitive advantage for any company. Besides, associated with the company studied was realized it should deploy a distribution center strategically located in a region with a range of potential customers.

For Macaé DC, it was obtained a saving in lead time of one day, whereas previously all orders from Macaé city and region were carried out within two days. From this point, the new model delivered at the same day as ordered.

This reduction of $100 \%$ over the previously practiced costs, generating substantial profits in terms of competitiveness and greater ability to service small boats that are moored by often for just one day.

Macaé region is a major oil producer and for this reason there are many clients as potential oil platforms with different engines in their structures, beyond docked boats and several bases motor oil dealers for small boats and motorboats.

In this segment a deadline for delivery virtually unbeatable currently adopted is 12 hours. This change of time delivery generated a sales increase and a higher profit margin due to the urgent needs of clients products. 
Another benefit gained from opening the DC is the possibility of Espírito Santo state attendance via Macae city which would generate a 1 day saving on the leadtime, as well as cost reduction in freight and warehouse operation fixed cost.

\subsubsection{Obtained Results in DC Macaé-RJ}

This distribution center had not a great reduction in freight cost, which in this case was only circa $8 \%$ reduction. Besides, such amount is related to the cargo insurance cost reduction due to movement amongst branches using standard price as previously mentioned.

The major difference was the cost of stay reduction awaiting berthing of vessels, due to the fact the goods out closest to ship you can get the load only when there is a better confirmation of the ship's berthing that reduced spending stays at the port awaiting berthing around $80 \%$.Before using this distribution center the company would spend around $\mathrm{R} \$ 28.000,00 /$ month in the locality with costs of travel and these values are currently at average $R \$ 5.600,00 /$ month, generating estimated annualized cost reduction of $R \$ 268.800,00$.

Related to fault reduction were not achieved significant decreasing, according to data previously collected for the DC implementation. The relative return and delivery invoices issued revolved only $0.2 \%$ and this index yielded no significant reduction after operation starting from the distribution center.

Considering punctual delivery, the index was at $92 \%$ rate before DC operations, and six months after its implementation analysis found this ratio reached $99 \%$. There is no doubt the great warehouse advantage was sales increase generated due to the benefit of the lead time for Navy serving customers (ie. ships, oil platforms and businesses in the region that serve smaller vessels). This increase in sales in the last survey conducted by Company $X$ based on the second half of 2013 shows that compared to the same period of six months prior to the project being implemented reached a sales increase of $150 \%$ over the previous period, which undoubtedly was the greatest warehouse advantage. 


\subsection{Case Stdudy 2: Distribution Center in Piracicaba-SP}

Piracicaba supplies São Paulo state, where Company $X$ has several industrial customers in the region such as companies grinding sugar cane and ethanol production and assembly plants tractors and vehicles of the locality.

The entire São Paulo state would be supplied by this warehouse serving as support to Vale do Paraíba region. Another important point that led the corporation to build DC in this locality was a synergy created with one of its major customer distributors for its products in Brazil: the distribution center Piracicaba was a project developed with this partner.

Checking the Piracicaba case was identified that benefits generated by reducing lead time boosted sales in the region, and generate an improvement in company's customer relationship. Thus, customers fulfill their orders closer to the actual date of use due to reduced distance and greater assertiveness of on-time deliveries. The two days reduction in each city route provided almost $100 \%$ decreasing in lead time.

Tax benefit generated a huge saving for organization in balancing ICMS (tax on sale of goods and services). ICMS works as follows: the first concept is that this tax is collected by each state apart; the second concept is that tax works somewhat like a scale because, when a company sells a particular product within a state tax is collected and when a particular company buys in the same state tax is credited in the same account where later he was charged, i.e., is only deducted from the balance sheet of this particular company tax and if this balance is positive it is reset every year.

Whereas the studied organization buy several products imported via the port of Santos, which are products of high added value account ICMS always had a positive balance in the state of São Paulo, then through sales in the state in question the Company $X$ has balanced best this tax.

Another benefit generated in this location is bound to reduce storage costs. Before structuring the company for this branch often low demands and lack of space in the plant generated a cost of stay in port of Santos and someone higher towering container rent. With the implementation of this distribution center is no longer reality: load is allocated in the warehouse where the storage cost is well below the port. 
Still analyzing this case, another important point is related to reverse logistics container with waste oil from large factories in the region, previously the customers claimed it was too expensive ship this product to be refined in Rio de Janeiro plant. With DC implementation, the Company $X$ agreed with these customers upon delivery of these containers. So it would be collected for return and subsequently consolidated to be refined again and sold as slop (refined oil mixed again).

This change allowed an increase in waste return which makes Company $X$ ensuring larger parts of its products are not contaminating the environment besides bringing a benefit with slop sales.

\subsubsection{Obtained Results in DC Piracicaba}

Analyzing the results this case can be seen a number of improvements: IPE Index (on-time delivery) enhancement - before distribution center this index was $92 \%$ deliveries and it rose to almost total efficiency (99.2\%).

Relating damage index, it also occurred an improvement reducing from $1 \%$ to $0.4 \%$ invoices delivered devolution occurring due to product damage. This index remains constant decreasing possibly associated with the use plant transfer to the DC via enclosed trailer and whole load pallets.

Another point diagnosed as positive outcome was the reduction in freight costs which generated a $10 \%$ reduction per shipment, which in absolute values generated a reduction in average freight cost per month of $R \$ 12.000,00$, which revolves annualized around $R \$ 140.000,00$ reducing overall shipping cost (insurance cost reduction is already within shipping costs).

Piracicaba DC had its costs reduced associated with allocated containers at the port of Santos, which generated a great result of retrenchment due to high costs for keeping a container stored in the port area. Whereas the daily cost of staying with the cargo at the port of Santos in the waiting room for unloading plant in Rio de Janeiro revolved average four dollars per day (4USD/day) per container per month. Therefore, Company $X$ spent up to $R \$ 130.000,00$ with containers at the port, and this value was reduced to $R \$ 40.000,00$ monthly, which means, cost reduction of over a million dollars per year. 
Checking increased sales generated from logistics new structure and strategic operation in sales to large grinding mills in the region reached an increase of $12 \%$. This volume has always been high increasing even larger revenues. The overall increase in sales in the locality analyzed in six months historical data reached $11 \%$.

Thus we can see that this was more a place where he brought a number of benefits for the organization becoming a pivotal support for the company was able to acquire this growth period studied.

\subsection{Fieldwork results analysis}

Another research step taken in this study was an interview conducted with five logistics professionals. A list of nine questions related to the topic was presented and then answered by them. The specialist functions range from: warehouse supervisor, performance analyst, logistics assistant, cargo assistant (scheduling) and logistics coordinator.

Nine questions were developed on the topic addressed in this work where it was possible to identify professional pattern answers. As an initial example is a list of answers were organized into a table addressing what were the three main benefits that the opening of a distribution center brings.

Table 1: Standard of Survey Answers - Main benefits of DCs implementation

\begin{tabular}{|c|c|c|c|c|c|}
\hline $\begin{array}{c}\text { Distribution Center Implementation } \\
\text { Benefits }\end{array}$ & $\begin{array}{c}\text { Logistics } \\
\text { planner }\end{array}$ & Coordinator & DC leader & $\begin{array}{c}\text { Performance } \\
\text { assistant }\end{array}$ & $\begin{array}{c}\text { Performance } \\
\text { analist }\end{array}$ \\
\hline Freight cost $\downarrow$ & $\mathrm{x}$ & $\mathrm{x}$ & $\mathrm{x}$ & $\mathrm{x}$ & $\mathrm{x}$ \\
\hline Lead time $\downarrow$ & $\mathrm{x}$ & $\mathrm{x}$ & $\mathrm{x}$ & $\mathrm{x}$ & $\mathrm{x}$ \\
\hline Production Capability $\uparrow$ & $\mathrm{x}$ & & & & \\
\hline Competitive Gain & & $\mathrm{x}$ & & & $\mathrm{x}$ \\
\hline Tax Benefits & & & & $\mathrm{x}$ & \\
\hline Customer service flexibility & & & $\mathrm{x}$ & & \\
\hline
\end{tabular}

As it can be seen the majority of answers are related to factors reducing freight cost and reducing delivery time, indicating that in the professional understanding these are really the key benefits. Also identified in the pattern of responses to the public questioned the main benefit to the client is to reduce the delivery time, because it can decrease their safety stock considering that one can 
order more compared to its real consumption need, which undoubtedly reduces final cost to customer and generates a lower risk of shortages.

Another point highlighted in this research was related to working through the distribution centers operation influencing product quality. What according to research collaborators this form of logistics network reduces faults rates on product packaging, because in long commutes products are consolidated and unitized. In addition, even modal change also reduces the risk of failures, once the route from each branch are shorter, which in turn reduces risks.

Most respondents believe the greatest impediment to distribution centers is the initial fixed cost of full operation of that facility. Finally the research could fulfill its role within professionals addressing issues already listed in this work, ratifying with linking information.

\subsection{Enterprise Current Status (2012 basis)}

Currently the company aims to consolidate prominently its second position in market share and continuing distribution centers implementation throughout the country by partnering with key distributors which will now become direct subsidiaries of the Company $\mathrm{X}$.

The current scenario shows that the market is still growing, but at a decelerated pace as practically the entire world economy. Another important topic discussed by the company nationwide is the slowing production of vehicles which generates a great impact on the analyzed company.

It is being analyzed the possibility of many distributors become distribution centers themselves. The DCs cases already deployed were considered satisfactory stimulating the company to expansion of 16 and 22 DCs over the country, as well as considering the possibility of opening a branch in Argentina.

The aforementioned information shows that Company $X$ continues to seek improvement in order to gain advantage over its competitors. Besides, it looks forward to nurturing its customers, increasing market share and using logistics enhancement through implementing a strategic vision number of distribution centers. 


\section{FINAL CONSIDERATIONS}

This work aimed to show the benefits introducing distribution centers improving results, considering the deployment of structured and strategic manner. Thus, it was taken as the basis of study a national company of lubricants industry to assist in the presentation of the idea, linking benefits and results to show these positive transformations.

Both studies were based on the Brazilian Southeast region. The overall benefits were identified as reduction in lead time, cost reduction, obtaining production space in the production plant between amongst other benefits. Through the implementation of this project Company $X$ could boost its sales, increased market share arising from the fifth to second place in sales. The study also showed business positive results such as delivery time reduction, ratings of on-time deliveries improved, transportation costs reduction, waste mitigation and raised sales.

This paper also presented a vision of how professionals see the benefits of distribution centers, and finally scenario analysis before and after this deployment. In so using a national company in the lubricants market as this research object of study was possible to see the contribution this work brought improving their customer service level, reducing their deadlines through a structured plan based on company strategic logistics network.

This work could be used as a basis for possible studies focused on other classes or segments, as presented benefits of these stakeholders can be treated as a base for any business purpose. Thus associated with the content presented in this paper it could be realized the DC role within the strategy to be treated with its due importance making difference in any organization.

\section{REFERENCES}

ALVES, P. (2000) Implantação de tecnologias de automação de depósitos: um estudo de casos. Dissertação de Mestrado - Administração, Universidade Federal do Rio e Janeiro.

APTE, U.; VISWANATHAN, S. (2000) Effective cross docking for improving distribution efficiencies. International journal of logistics: research and applications, v. 3, n. 3.

BALLOU, R. (2006) Gerenciamento da cadeia de Suprimentos: Logística Empresarial.Porto Alegre: Bookman, $5^{\mathrm{a}} \mathrm{Ed}$. 
BOWERSOX, D.; CLOSS, D. J. (2001) Logística empresarial: o processo de integração da cadeia de suprimento. São Paulo: Atlas.

BOWERSOX, D.; CLOSS, D. J.; COOPER, B. (2002) Gestão Logística de Cadeias de Suprimentos. São Paulo: Bookman.

CALAZANS, F. (2001) Centros de distribuição. Gazeta Mercantil: Agosto.

CARVALHO, J. (2002) Logística. $3^{\mathrm{a}}$ ed. Lisboa: Edições Silabo.

CHRISTOPHER, M. (1997) Logística e gerenciamento da cadeia de suprimentos: estratégias para a redução de custos e melhoria dos serviços.

São Paulo: Pioneira.

FIGUEIREDO, K. F.; FLEURY, P. F.; WANKE, P. (2000) Logística Empresarial : A perspectiva brasileira - Centro de estudos em Logística - CEL. São Paulo: Atlas. KOTLER, P. (1999) Marketing para o século XXI: como criar, dominar e conquistar mercados. São Paulo: Atlas.

LEITE, P. R. (1998) Canais de Distribuição Reverso. Revista Tecnologística São Paulo. N 28 e 29, Março e Abril.

MORENO, F. (2001) Logística e a Vantagem Competitiva. Disponível em: http://www.guiadelogistica.com.br. Acesso em 07.03.2014.

NOVAES, A. G. N. (2001) Logística e Gerenciamento da Cadeia de Distribuição. Rio de Janeiro, Campus.

NUNES, G.; HAIGH, D. (2003) Marca: Valor do intangível, medindo e gerenciando seu valor econômico. São Paulo: Atlas.

PIZZOLATO, N.; PINHO, A. (2003) A regionalização dos centros de distribuição como solução logística. Revista Tecnologística, Ano VIII, n. 87.

ROGERS, D.; TIMBE-LEMBKE. (1998) Going backwards: reverse logistics trends and practices. University of Nevada, Reno, CLM, Reverse Logistics Executive Council. Available at http://www.rlec.org/reverse.pdf, Accessed on 10.11.2013.

SANTA LUCIA, C. (2012) Gestão Empresarial - A importância do FORECAST. Avaiable at http://www.contabeis.com.br/artigos, Accessed on 16.05.2014.

SINDICOM (2014). Available at http://www.sindicom.com.br/ Accessed on 14.04.2014

SLACK, N. et al. (2002) Administração da Produção. Ed. compacta, São Paulo: Atlas. 